\title{
Az élelmi rostokkal kapcsolatos fogyasztói ismeret - Hazai kérdőíves felmérés eredményei
}

\author{
Szúcs Viktória dr. ${ }^{1}$ - Harangozó Júlia ${ }^{1}$ - Raquel P. F. Guiné dr. ${ }^{2}$ \\ ${ }^{1}$ Nemzeti Agrárkutatási és Innovációs Központ - Élelmiszer-tudományi Kutatóintézet, Budapest \\ ${ }^{2}$ CI\&DETS/Escola Superior Agrária do Instituto Politécnico de Viseu, Viseu, Portugália
}

\begin{abstract}
Bevezetés: Az élelmi rostok az egészséges és kiegyensúlyozott táplálkozás kulcselemei, amelyek rendszeres fogyasztása számos betegség kockázatát csökkentheti. Célkitüzés: Jelen munka célja a magyar fogyasztók élelmi rostokkal kapcsolatos ismeretének, vásárlási döntésben betöltött szerepének feltárása, valamint a jelenleg használt és a fogyasztást előremozdító lehetséges információforrások megismerése volt. Módszer: A kérdőíves megkérdezést 303 magyar felnőtt fogyasztó segítségével végezték. Eredmények: Az élelmi rostok forrásait tekintve a résztvevők bizonytalanok voltak, míg a rostfogyasztás egészségügyi hatásainak ismerete viszonylag alapos volt. Az internet jelentős információs forrásként jelent meg a témában, azonban az eredmények rámutatnak az iskolai oktatás fontosságára is. Az élelmi rostban gazdag élelmiszereket gyakrabban fogyasztók, a nők, valamint a 45 éven felüli résztvevők az élelmi rostokkal kapcsolatosan tudatos attitüdöt mutattak. Következtetések: A hazai fogyasztók kiegyensúlyozott táplálkozásának érdekében az élelmi rostokkal kapcsolatos hiteles és gyakorlati elemeket tartalmazó iránymutatás és oktatás elengedhetetlen, amelynek eredményeképpen a latens ismeret várhatóan a fogyasztók vásárlási döntéseiben tudatosan is meg fog jelenni. Orv. Hetil., 2016, 157(8), 302-309.
\end{abstract}

Kulcsszavak: élelmi rost, fogyasztói ismeret, kérdőíves megkérdezés, vásárlási döntés

\section{Consumer knowledge about dietary fibre - Results of a national questionnaire survey}

Introduction: Dietary fibres are key elements of healthy and balanced diet. Aim: The aim of the present study was to explore consumers' knowledge considering fibre, their role in the purchasing decisions, and the cognition of the currently used as well as the possible information sources to encourage the fibre consumption. Method: A questionnaire survey was conducted with 303 respondents. Results: Knowledge about the fibre sources has showed a kind of uncertainty of the respondents, while knowledge about their possible health effects was relatively profound. Internet appeared as a remarkable information source in the topic; however, results pointed out the importance of education, too. Participants more often consuming foodstuffs rich in fibre, women and respondents over 45 years old showed conscious attitudes regarding fibres. Conclusions: Guidelines and education containing authentic information and practical elements are essential, and as a result, consumers' latent knowledge will appear in their conscious food choice decisions.

Keywords: dietary fibre, consumer knowledge, questionnaire survey, consumer decision

Szücs, V., Harangozó, J., Guiné, R. P. F. [Consumer knowledge about dietary fibre - Results of a national questionnaire survey]. Orv. Hetil., 2016, 157(8), 302-309.

(Beérkezett: 2015. december 16.; elfogadva: 2016. január 7.) 


\section{Rövidítések}

FINUT = (Iberoamerican Nutrition Foundation $)$ Iberoamerikai Táplálkozási Alapítvány; OÉTI $=($ National Institute for Food and Nutrition Science) Országos Élelmezés- és Táplálkozástudományi Intézet; UFIC = (European Food Information Council) Európai Élelmiszer Információs Bizottság; WHO = (World Health Organization) Egészségügyi Világszervezet

Az élelmi rostok az egészséges és kiegyensúlyozott táplálkozás kulcselemei. A rostdús táplálkozás számos betegség kockázatát csökkentheti, mint a daganatos megbetegedések, a cukorbetegség, a szív- és érrendszeri megbetegedések, illetve az elhízás [1,2]. A táplálkozással kapcsolatos krónikus betegségek megelőzésének érdekében az Egészségügyi Világszervezet (World Health Organization - WHO) napi $25 \mathrm{~g}$ élelmi rost fogyasztását javasolja felnőttek számára [3]. A hazai reprezentatív táplálkozási felmérések eredményei azt mutatják, hogy a magyar felnőtt lakosság átlagos rostbevitele $(22,7 \pm 6,6)$ [4] nem éri el a nemzetközi ajánlást [5]. A férfiak átlagfogyasztása megközelíti $(25,0 \pm 7,0)$ [4], illetve némileg meg is haladja $(26,1 \pm 0,5 \mathrm{~g} / \mathrm{nap})$ [5] a javasolt mennyiséget, míg a nók fogyasztása nem éri el $(21,8 \pm 0,3 \mathrm{~g} /$ nap; $20,8 \pm 5,5)[4,5]$ ezt a mennyiséget. A hazai lakosság élelmirost-igényét legnagyobb mennyiségben cereáliák (34-40\%), zöldség- és főzelékfélék (33-34\%) fogyasztásából fedezi, míg kisebb mennyiségben gyümölcsök (16-22\%), száraz hüvelyesek (4-5\%) és egyéb élelmiszerek (6\%) fogyasztásával [5]. A hazai táplálkozási útmutató (Magyarország Nemzeti Táplálkozáspolitikája) [6] felhívja a figyelmet a rendszeres zöldség- és gyümölcsfogyasztás előnyeire, valamint a teljes kiőrlésú gabona és teljes gabonamagvakat tartalmazó élelmiszerek (például gabonapelyhek) fontosságára, azonban az élelmi rostok fogyasztásának tekintetében nem ad részletesebb iránymutatást. Az 1990-es évek végén az OÉTIben - az addig használt táplálkozási piramis és szivárvány átgondolása után - kialakításra került az egészséges táplálkozás házikója, amely alapját a teljes kiőrlésű gabonatermékek, valamint a friss zöldségek és gyümölcsök képezik [7]. A zöldség- és gyümölcsfogyasztást hazánkban a „Fogyasszon naponta $3 \times 3$-féle zöldséget, gyümölcsöt az egészségért!” mottójú „Naponta $3 \times 3$ ” program is igyekszik előremozdítani [8]. Az Iberoamerikai Táplálkozási Alapítvány (Iberoamerican Nutrition Foundation - FINUT) 2014-ben megjelent komplex táplálkozási piramisa - túlmutatva az eddigi ajánlásokon - a kiegyensúlyozott táplálkozás érdekében javasolja, hogy az elfogyasztásra kerülő cereália és cereáliatermékek legalább fele teljes kiőrlésü gabonatermék legyen [9].

A rostban természetes módon gazdag élelmiszerek (például zöldségek, gyümölcsök, hüvelyesek, teljes kiôrlésű termékek) mellett az élelmiszerüzletek polcain egyre nagyobb mennyiségben találhatunk megnövelt élelmirost-tartalmú élelmiszereket, úgynevezett funkcionális élelmiszereket. Azonban fontos megjegyeznünk, hogy mindamellett, hogy az élelmiszerek rostdúsítása - és ezzel együtt a gyártási melléktermékek, mint a törköly felhasználási lehetőségeinek vizsgálata - számos kutatási munka célkitûzése [10-13], az európai fogyasztók „természetesség" iránti igénye e termékek átütő sikerének útját állja [14]. További gondot jelent, hogy a jelölési szabályozásnak [15], illetve az összetett fogyasztói elvárásoknak a gyártók részéről történő megfelelésnek köszönhetően ezen élelmiszerek számos információt, logót tartalmaznak, amelyeket a fogyasztók gyakran nem vesznek figyelembe, illetve nem megfelelően értelmeznek. Az információtúlterheltség és a kognitív stressz elkerülésének érdekében a fogyasztók vásárlási döntéseiket igyekeznek minél egyszerúbb szempontok figyelembevételével meghozni [16], fóként az ár, a márka és a szokások által vezérelve [17]. Annak ellenére, hogy a fogyasztók tudatában vannak annak, hogy táplálkozásuk befolyásolja egészségi állapotukat [18], valamint számos betegség kezelésében és megelózésében fontosnak vélik az élelmi rostok fogyasztását, az általuk elfogyasztott mennyiség továbbra is alacsonynak tekinthető [19]. Az európai fogyasztók alig 38\%-a vásárol rendszeresen teljes kiőrlésú vagy rostdús élelmiszereket. Ennek oka lehet, hogy majdnem minden harmadik (29\%) fogyasztó kételkedik abban, hogy a megnövelt rosttartalom valódi kedvező egészségügyi hatást okoz, illetve $12 \%$-uk túlzóan drágának véli ezeket az élelmiszereket [20]. Urala és Läbteen$m \ddot{a} k i[21]$ a funkcionális élelmiszerek vásárlási hajlandóságának növeléséhez a fogyasztás „jutalom” érzésének (egészségügyi, etikai, érzékszervi), valamint a termékekkel kapcsolatos bizalom fokozását javasolja.

Jelen munkánk célja a magyar fogyasztók élelmi rostokkal kapcsolatos ismeretének, vásárlási döntésben betöltött szerepének feltárása, valamint a jelenleg használt és a fogyasztást előremozdító lehetséges információforrások megismerése volt.

\section{Anyag és módszer}

Kutatási munkánkat 10 ország 12 intézményének részvételével zajlott nemzetközi együttmúködés keretében végeztük a portugáliai CI\&DETS Kutatóközpont Politechnikai Intézetének (CIßDETS Escola Superior Agrária do Instituto Politécnico) koordinálása mellett. Jelen tanulmányunkban a magyarországi eredmények kerülnek részletesebb bemutatásra. Adatgyújtésünket egy validált kérdőív segítségével végeztük [19,22] 2014-2015 őszi-téli időszakában. A kérdőív több részből állt: szociodemográfiai jellemzőket, élelmi rostok fogyasztási gyakoriságát, élelmi rostok ismeretét, az élelmi rostok és a különböző betegségek kapcsolatát, az élelmiszer-jelölések vásárlási döntésben betöltött szerepét feltáró, valamint a jelenlegi és a potenciális információs forrásokat vizsgáló kérdésekből. Az adatok elemzését leíró statisztikák segítségével értékeltük, valamint a válaszok rostdús élelmiszerekre vonatkozó fogyasztási gyakorisági és szociodemográfiai metszetének vizsgálatát kereszttáblás 
1. táblázat |A megkérdezettek szociodemográfiai megoszlása

\begin{tabular}{lcc}
\hline & $\mathrm{N}$ & $\%$ \\
\hline Nem & 303 & 100,0 \\
Nő & 217 & 71,6 \\
Férfi & 86 & 28,4 \\
Kor & 302 & 100,0 \\
$18-24$ éves & 147 & 48,7 \\
$25-34$ éves & 92 & 30,5 \\
$35-44$ éves & 31 & 10,3 \\
45 év feletti & 32 & 10,6 \\
Legmagasabb iskolai végzettség & 303 & 100,0 \\
Érettségi vagy alacsonyabb & 132 & 43,6 \\
Felsófokú végzettség & 171 & 56,4 \\
Lakhely típusa & 303 & 100,0 \\
Vidék & 41 & 13,5 \\
Város & 262 & 86,5 \\
\hline
\end{tabular}

elemzések használatával végeztük. Az eredmények értékelését 303 válaszadó adatai segítségével végeztük IBM SPSS Statistics 23 programcsomag segítségével.

A vizsgált minta szociodemográfiai jellemzése alapján elmondható, hogy a nők magasabb arányban vettek részt $(71,6 \%)$ a vizsgálatban, mint a férfiak $(28,4 \%)$. A kitöltők közel fele 18-24 év közötti volt (48,7\%), míg 30,5\%-uk a 25-34 éves korcsoportba tartozott. A résztvevők jelentős része felsőfokú végzettséggel rendelkezett $(56,4 \%)$, valamint a lakhely tekintetében többségük városi lakos volt $(86,5 \%)$ (1. táblázat).

A résztvevők fogyasztási szokásai tekintetében elmondható, hogy alig több mint 30\%-uk állította, hogy naponta többször fogyaszt zöldséget/salátát tartalmazó ételeket, illetve gyümölcsöt. Kedvezőtlen eredmény, hogy több mint $10 \%$-uk a heti rendszerességnél is ritkábban (zöldség/saláta: 14,5\%; gyümölcs: 9,3\%), illetve soha (zöldség/saláta: 0,7\%; gyümölcs: 2,3\%) nem fogyaszt zöldséget vagy gyümölcsöt. Az Eurostat 2008-as adatai kedvezőbb képet mutatnak a hazai zöldség- és gyümölcsfogyasztásról. A magyar fogyasztók több mint fele naponta egyszer vagy legalább kétszer fogyaszt zöldséget $(52,7 \%)$ és gyümölcsöt $(68,3 \%)$, és alig több mint $5 \%$-uk heti rendszerességnél kevesebb alkalommal vagy soha [23]. A vizsgálatunk során tapasztalt alacsony fogyasztásra némi magyarázatot adhat, hogy az adatgyưjtés az őszi-téli időszakban történt, amikor a friss zöldségek és gyümölcsök elérhetősége, változatossága némileg korlátozottabb. A teljes kiőrlésű gabonatermékek rendszeres fogyasztása még ettől is rosszabb képet mutat. Napi többszöri alkalommal csupán 10\%-uk fogyaszt rostdús kenyeret vagy tésztát, míg 13,2\%-uk heti rendszerességnél is ritkábban és 17,8\%-uk soha nem fogyaszt ilyen élelmiszereket (1. ábra).
A szociodemográfiai tényezőkkel végzett kereszttáblás elemzés alapján elmondható, hogy sem a legmagasabb iskolai végzettség, sem a lakhely típusa nem befolyásolta jelentősen a rostdús élelmiszerek fogyasztásának gyakoriságát. A nem tekintetében megállapítható, hogy a férfiak gyakoribb gyümölcsfogyasztóknak bizonyultak, mint a nők ( $\mathrm{p}<0,05$; Cramer's V =0,143). A gyümölcsök naponta többször történő fogyasztása a 45 éven felüli résztvevők tekintetében jellemzőbb volt, mint a fiatalabb korcsoportok tagjaira $(\mathrm{p}<0,001$; Cramer's V = 0,247). A hetente többszöri gyümölcs- $(\mathrm{p}<0,001$; Cramer's $\mathrm{V}=$ $0,247)$ és zöldségfogyasztás $(\mathrm{p}<0,05$; Cramer's $\mathrm{V}=$ $0,141)$ - szemben a többi korcsoport tagjaival - a 18-24 éves résztvevőkre volt leginkább jellemző.

\section{Eredmények}

\section{Az élelmi rostokkal kapcsolatos ismeret}

Az élelmi rostok forrásainak vizsgálata alapján elmondható, hogy a résztvevők csupán 33\%-a értet egyet azzal az állítással, amely szerint azok csak növényi élelmisze-

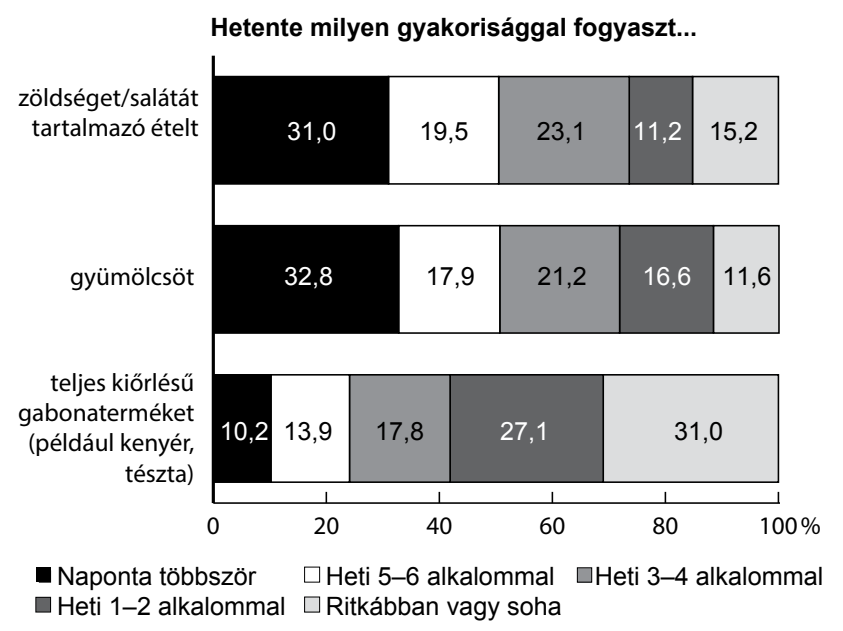

1. ábra

| A megkérdezettek rostdúsélelmiszer-fogyasztási szokásai

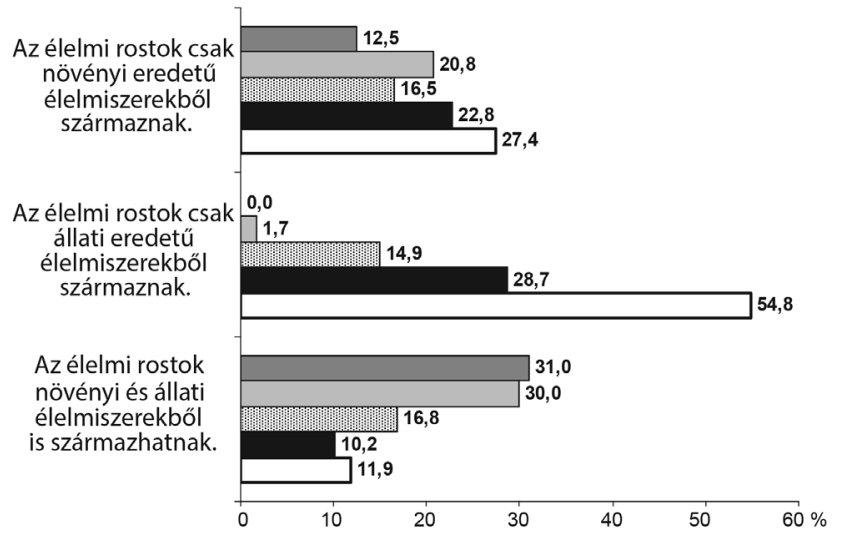

口Egyáltalán nem értek egyet @ Inkább nem értek egyet $\quad$ Egyet is értek 口Inkább egyetértek 口Teljes mértékben egyetértek meg nem is

\begin{tabular}{l|l} 
2. ábra & $\begin{array}{l}\text { Az élelmi rostok forrásának ismeretét vizsgáló kérdések eredmé- } \\
\text { nyei }\end{array}$
\end{tabular} 


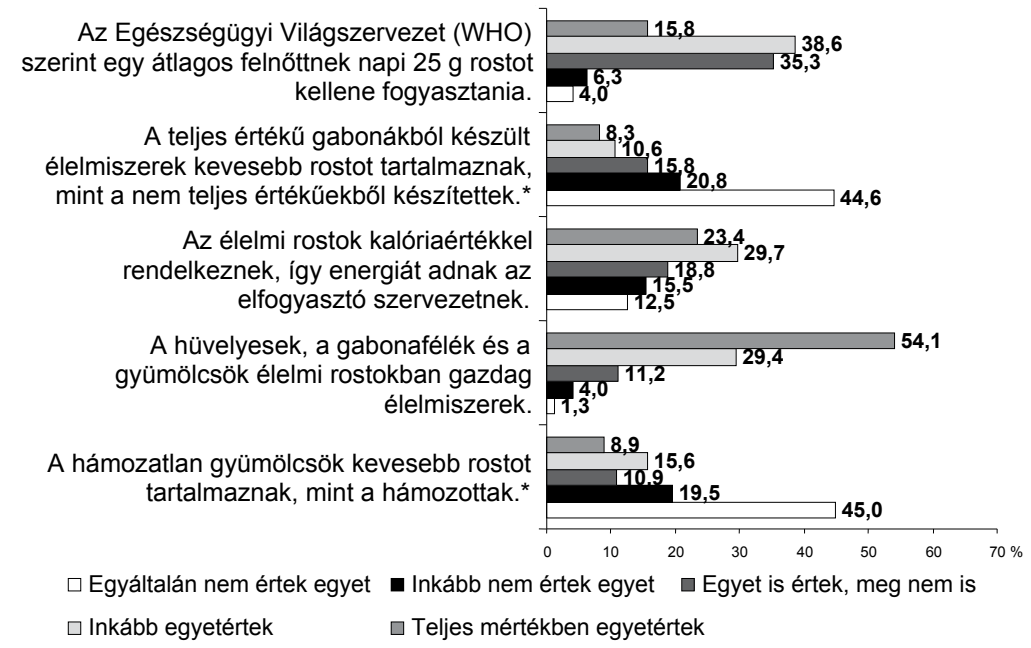

3. ábra

| Az élelmi rostokkal kapcsolatos ismeretet vizsgáló kérdések eredményei ( ${ }^{\star}$ fordított kérdések)

rekből származhatnak, míg a résztvevők fele inkább nem vagy egyáltalán nem értett egyet ezzel az állítással. Az állati eredetű élelmiszereket többségük $(83,5 \%)$ nem vélte jelentős élelmirost-forrásnak. A válaszadók bizonytalanságát mutatja, hogy több mint $60 \%$-uk egyetértett azzal, hogy az élelmi rostok növényi és állati élelmiszerekből is származhatnak. Továbbá a résztvevők 15-16\%a a válaszadás során inkább a tartózkodást („Egyet is értek, meg nem is") választotta (2. ábra).

A fogyasztási szokásokat vizsgáló kérdésekkel végzett kereszttáblás elemzés nem mutatott szignifikáns ( $p$ $<0,05)$ kapcsolatot, azonban az eredmények tendenciája alapján elmondható, hogy a rostdús (zöldség/saláta, gyümölcs, teljes kiőrlésú gabonatermékek) élelmiszereket napi rendszerességgel fogyasztók nagyobb arányban azonosították a növényi élelmiszereket élelmi rostok forrásaként. A szociodemográfiai tényezők alapján megállapítható, hogy a 35 éven felüli résztvevők magasabb arányban értettek egyet az élelmi rostok növényi eredetével $(\mathrm{p}<0,05$; Cramer's $\mathrm{V}=0,167)$, míg a fiatalabb válaszadók a növényi és állati forrást is valósnak vélték $(\mathrm{p}<0,05$; Cramer's V = 0,147).

Kérdőívünkben a részletesebb ismeretet további állítások segítségével vizsgáltuk. A teljes értékü gabonákból készült élelmiszerek rosttartalmát a válaszadók helyesen magasabbnak ítélték a nem teljes értékü gabonatermékekkel szemben. Szintén kedvező eredmény, hogy a hüvelyeseket, gabonaféléket és a gyümölcsöket élelmi rostban gazdag élelmiszerekként azonosították a résztvevők. Tendenciaszerűen ismét elmondható, hogy a zöldséget/ salátát, gyümölcsöt $(\mathrm{p}<0,05$; Cramer's $\mathrm{V}=0,196)$ és teljes kiőrlésú gabonákból készült élelmiszereket napi rendszerességgel fogyasztók magasabb arányban ismerték az utóbbi két állítást. A 18-24 éves kitöltők bizonytalanok voltak abban, hogy a hüvelyesek, gabonafélék és a gyümölcsök valóban rostdús élelmiszerek-e, míg a tőlük idősebbek szignifikánsan magasabb arányban értettek egyet ezen állításunkkal ( $\mathrm{p}<0,05$; Cramer's $\mathrm{V}=0,151)$. A há- mozatlan gyümölcsök magasabb rosttartalma - mint egy szülőről gyermekre szálló tudás - szintén ismert volt a kérdőívet kitöltők számára. Azonban kedvezőtlen eredmény, hogy az Egészségügyi Világszervezet ajánlását alig több mint 10\%-uk ismerte. A gyümölcsöt és teljes kiőrlésü termékeket, de fóként a zöldségeket $(\mathrm{p}<0,05$; Cramer's $\mathrm{V}=0,191)$ napi rendszerességgel fogyasztók alaposabb ismerettel rendelkeztek az ajánlásról. Az élelmi rostok kalóriatartalma $(2 \mathrm{kcal} / \mathrm{g})$ [24] olyannyira ismeretlen tény volt a résztvevők számára, hogy még a rendszeresen rostdús élelmiszereket fogyasztók sem vélték valósnak (3. ábra).

\section{Az élelmi rostok és a különbözö betegségek közötti kapcsolat ismerete}

A résztvevők többsége $(88,2 \%)$ egyetértett abban, hogy: „Az élelmi rostok megfelelő mennyiségben történő fogyasztása megelőzheti és/vagy hozzájárulhat a betegségek kezeléséhez." A különböző betegségek részletesebb vizsgálata alapján arra lehet következtetni, hogy a kitöltők alapvetően ismerik az élelmi rostok kedvező hatásait. Legerősebb kapcsolatot a „székrekedés kezelése” esetében tapasztaltunk, amely állítással a résztvevők 83,8\%-a értett egyet. Az élelmi rostok fogyasztásának kapcsolata az „elhízás” (72,9\%), a „bélrák” (72,3\%), a „szív- és érrendszeri betegségek” $(69,6 \%)$, valamint a „magas koleszterinszint kezelése és megelózése" (68,6\%) szempontjából szintén a résztvevők többsége számára ismert volt. A rostfogyasztás és a „vitaminok és ásványi anyagok hiányának kezelése” (60,0\%), valamint a „cukorbetegség kezelése" $(56,6 \%)$ között már némileg gyengébb kapcsolat figyelhető meg. A betegségek listája két ellenőrző kérdést tartalmazott a „látási problémák”, illetve a „mellrák kezelése" tekintetében. Mivel e kérdések esetében jelentősen alacsonyabb arányú egyetértést tapasztaltunk, megállapítható, hogy a résztvevők válaszadásuk során kellően figyelmesek voltak (4. ábra). 


\section{Az élelmi rostok megelőzhetik és/vagy hozzájárulhatnak...}

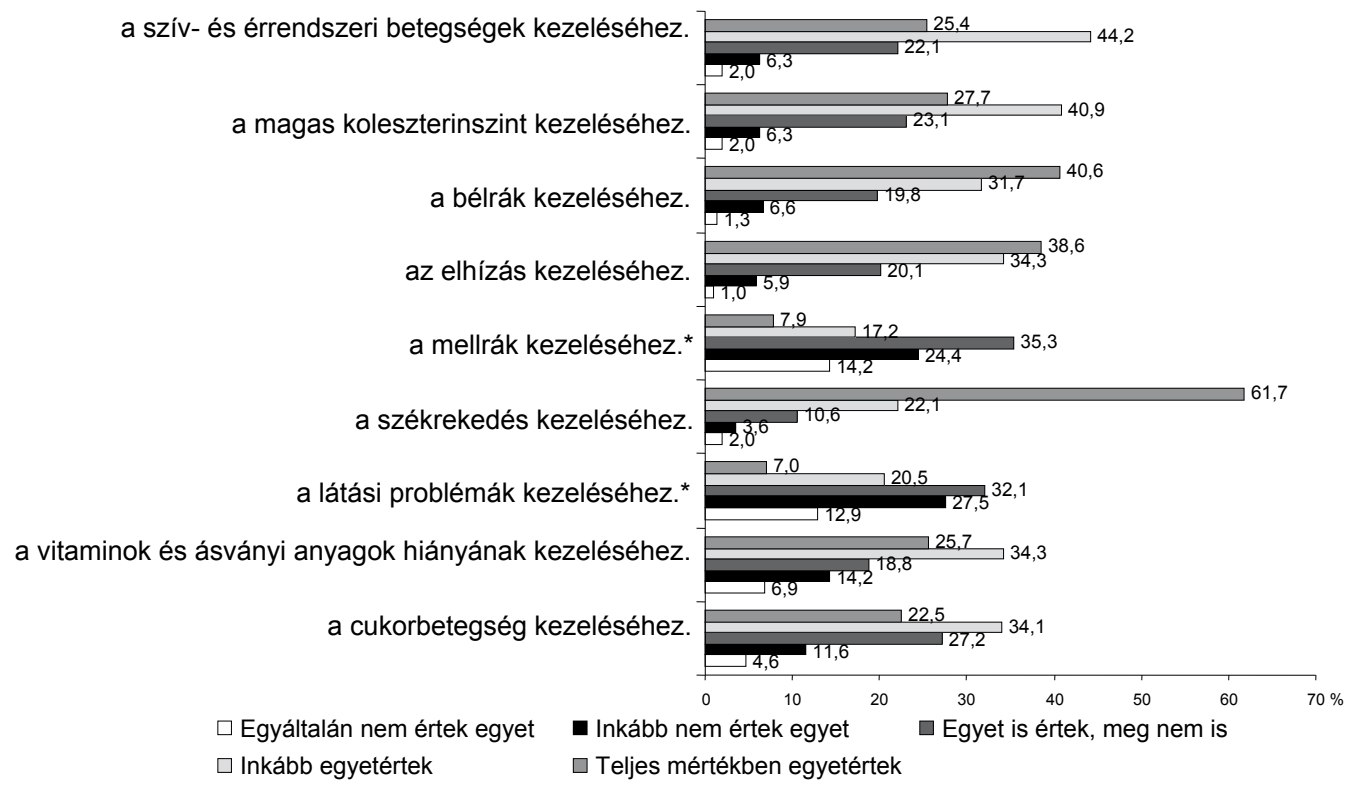

4. ábra

| Az élelmi rostok és a különböző betegségek közötti kapcsolatot vizsgáló kérdések eredményei (

\section{Információs források az élelmi rostok témájáról}

A kérdőívben felsorolt kérdések fontossági sorrendjének tekintetében megállapítható, hogy - a többi tényezőtől szignifikánsan elkülönülve ( $\mathrm{p}<0,001$; Cramer's V>0,200) - az élelmi rostok témájával az ,interneten” találkoznak leggyakrabban a résztvevók, valamint szintén ezt a forrást vélték a legalkalmasabbnak a fogyasztás előremozdításának érdekében. Ezzel szemben a „rádió” - a többi forrástól szignifikánsan elkülönülve $(\mathrm{p}<0,001$; Cramer's $\mathrm{V}>0,200)$ - jelenlegi és potenciális jelentősége nagyon alacsonynak mutatkozott. A jelenlegi források tekintetében a "magazinok, könyvek” is említhetók, azonban a téma előremozdításában már nem vélték jelentős csatornának a válaszadók. Annak ellenére, hogy az „iskolában” és a „televízióban” ritkábban találkoznak az élelmi rostok témájával, a fogyasztás növelésének szempontjából viszonylag kedvező lehetőségnek ítélték. Kedvezőtlen eredményként tapasztaltuk, hogy az „egészségközpontok, kórházak" mind a jelenlegi, mind a jövőbeni tájékoztatás szempontjából kedvezőtlen megítélést kaptak (5. ábra).

A fogyasztási gyakoriság adatokkal végzett kereszttáblás elemzése alapján egyetlen esetben találtunk statisztikailag $(\mathrm{p}<0,05)$ kimutatható kapcsolatot, amely alapján a zöldségeket naponta többször fogyasztó résztvevők jelentősen gyakrabban találkoznak az élelmi rostok témájával „magazinokban és könyvekben”, mint a ritkábban fogyasztók (Cramer's V = 0,194). Ennek oka lehet, hogy ők tudatosabban odafigyelnek ezekre a cikkekre, és valószínúsíthetően keresik is a kapcsolódó irodalmat. A szociodemográfiai tényezők segítségével végzett elemzés rámutatott, hogy az élelmi rostok témájával a nők - szemben a férfiakkal - gyakrabban találkoznak „magazinokban, könyvekben”. Ennek oka lehet a számos nói magazin, amelyek előszeretettel tárgyalnak egészséges táplálkozással és annak vonatkozásaival kapcsolatos témákat. A nők jelentősebb forrásként jelölték meg e témában a "rádiót", mint a férfiak ( $\mathrm{p}<0,05$; Cramer's $\mathrm{V}=$ $0,227)$.

\section{Cimkeinformációkkal kapcsolatos fogyasztói attitüdök}

A résztvevők több mint fele bevallása alapján mindig vagy gyakran megnézi az élelmiszerek címkeinformációját. Kedvező eredmény, hogy csupán 4,3\%-uk állította, hogy soha nem nézi meg a csomagoláson található információkat. Az élelmiszerek csomagolásán a tápanyag-információkat már ritkábban tekintik meg a válaszadók $(21,1 \%$ ritkán és $7,3 \%$ soha $)$. A rosttartalmat a tápanyaginformációkhoz képest még ritkábban ellenórzik a kitöltők ( $29,7 \%$ ritkán és $31,4 \%$ soha), valamint csak kevés résztvevő vásárlási döntését befolyásolja érdemben az élelmiszerek közötti vásárlás során (16,2\% gyakran vagy mindig). Majdnem minden harmadik válaszadó soha nem nézi meg az élelmiszerek csomagolási információi között a rosttartalmat, illetve ez a tényezô egyáltalán nem befolyásolja termékválasztásukat (6. ábra).

A rostdús élelmiszerek fogyasztási gyakoriságával végzett kereszttáblás vizsgálat rámutatott, hogy a zöldségeket $(p<0,05$; Cramer's $V=0,169)$, gyümölcsöket $(p<0,05$; Cramer's $V=0,170)$ és teljes kiőrlésû́ gabonatermékeket $(\mathrm{p}<0,05$; Cramer's $\mathrm{V}=0,168)$ naponta többször fogyasztók azonos termékek közötti döntéseik során - az alacsonyabb fogyasztási gyakoriságot mutató 

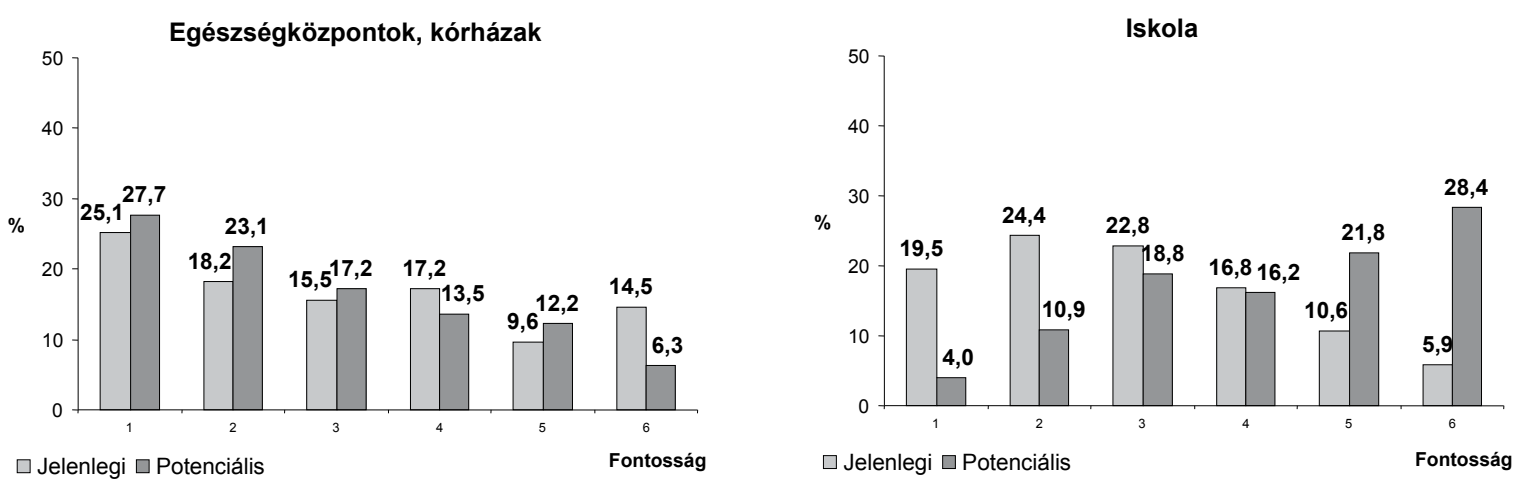

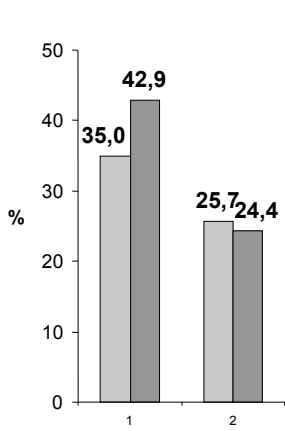

$\square$ Jelenlegi $\square$ Potenciális

Rádió
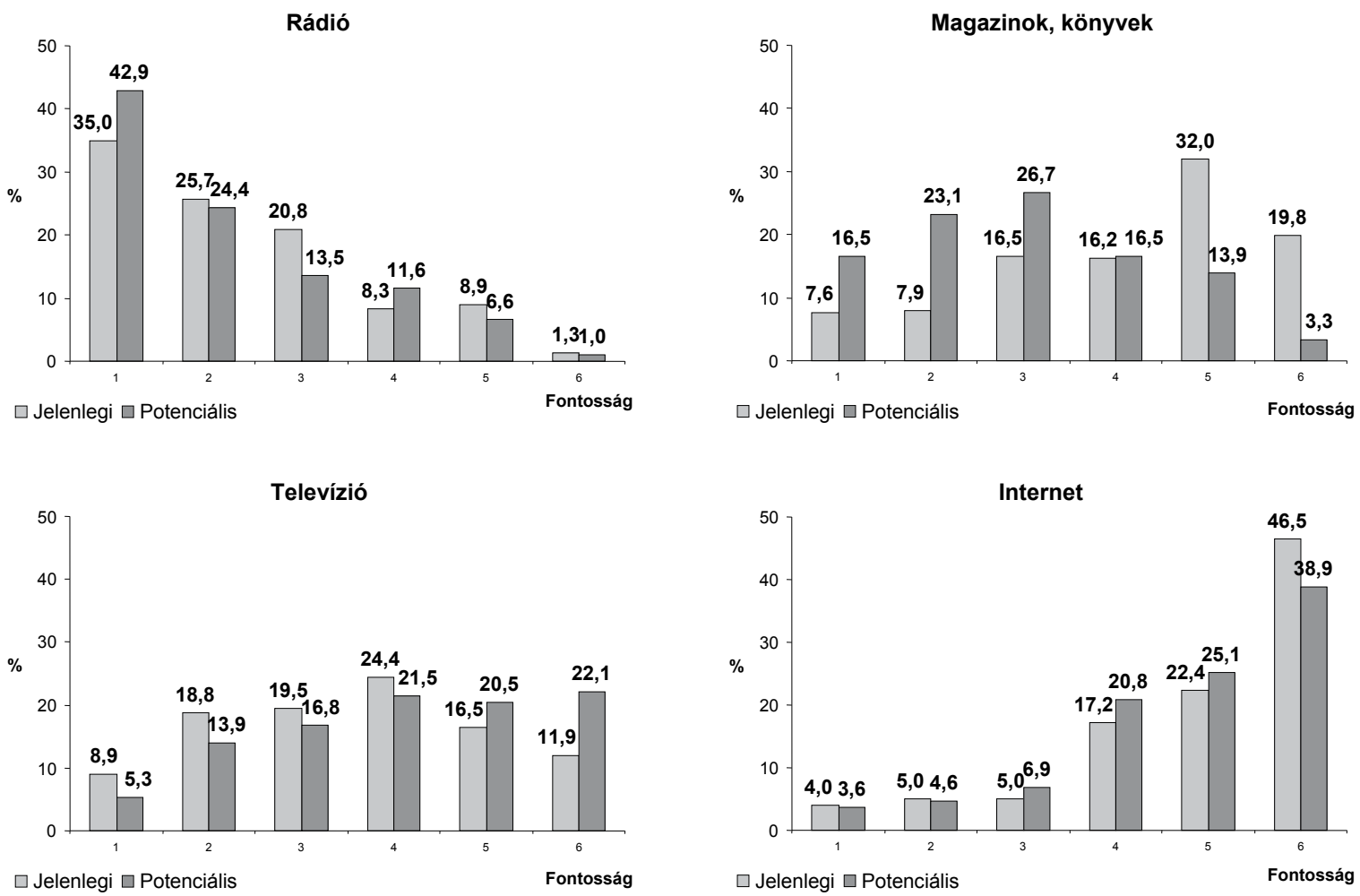

5. ábra |Az élelmi rostokkal kapcsolatos információforrások fontossága (1: legkevésbé fontos; 6: legfontosabb)

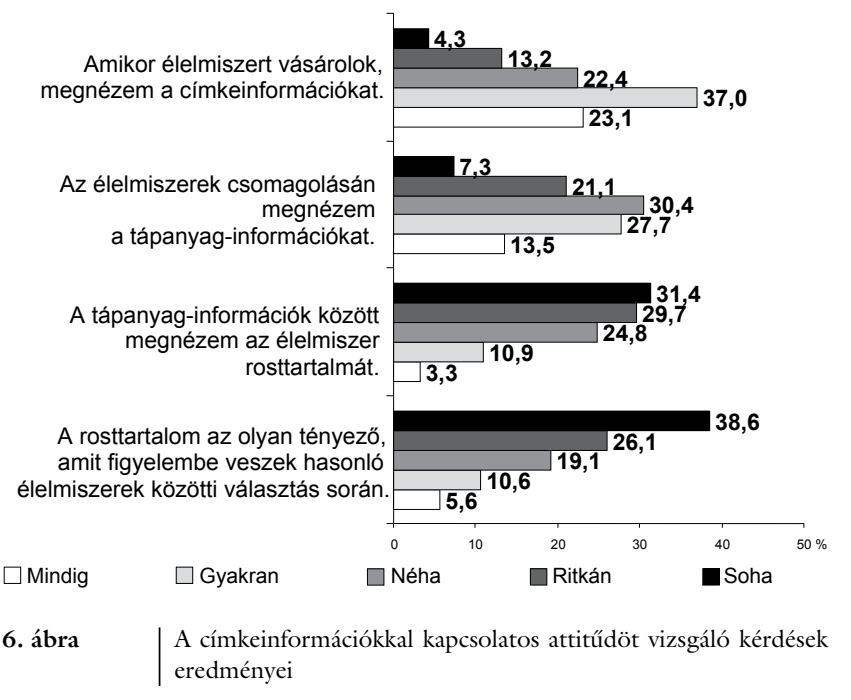

csoportokkal összehasonlítva - jellemzőobben inkább figyelembe veszik az élelmiszerek rosttartalmát. Továbbá a teljes kiőrlésú gabonatermékeket gyakran fogyasztók sűrún ellenőrzik az élelmiszerek címkéjén található információkat, azon belül a tápanyagadatokat is. Ennek oka lehet, hogy a teljes kiőrlésű gabonákból készült élelmiszerek megjelenése nem mindig utal annak összetételére, illetve előfordulhat, hogy a termék neve sem egyértelmú (például rozsos kenyér vagy rozskenyér). A női válaszadóink - szemben a férfiakkal - jellemzóbben gyakrabban megnézik az élelmiszerek címkeinformációit $(\mathrm{p}<0,05$; Cramer's $\mathrm{V}=0,197)$, valamint azonos élelmiszerek esetén figyelembe veszik azok rosttartalmát $(\mathrm{p}<0,05$; Cramer's $\mathrm{V}=0,208)$. A címkeinformációk tanulmányozása a magasabb végzettséggel rendelkezókre szintén jellemzóbb volt $(\mathrm{p}<0,05$; Cramer's $V=0,191)$, 
valamint a rosttartalom a 45 éven felüli kitöltők választási döntését erősebben befolyásolta, mint a fiatalabb résztvevőkét $(\mathrm{p}<0,05$; Cramer's $\mathrm{V}=0,180)$.

\section{Megbeszélés}

A civilizációs betegségek visszaszorításának egyik eszköze az egészséges és kiegyensúlyozott táplálkozás, amelynek egyik építőeleme az élelmi rost.

Kérdőíves megkérdezésünk eredményei alapján megállapítható, hogy a résztvevők élelmi rostokkal kapcsolatos ismerete bizonyos esetekben alaposnak, azonban számos esetben (például élelmi rostok forrásának ismerete) bizonytalannak tekinthető. Az élelmi rostok fogyasztásának egészségre gyakorolt kedvező hatásával megkérdezetteink viszonylag tisztában vannak, azonban - ahogy azt Martinho és szerzótársai is megállapították [19] - a fogyasztás gyakorisága ezt nem igazolja. A rostdús (zöldség, gyümölcs, teljes kiőrlésú gabonatermékek) élelmiszereket gyakran fogyasztók tudatosabb fogyasztói vonásokat mutattak. Ezen fogyasztói csoport tagjai valószínúsíthetően keresik és szívesen olvassák a témával kapcsolatos információkat, valamint vásárlási döntéseik meghozatala során odafigyelnek a termékek élelmirosttartalmára. A szociodemográfiai tényezők segítségével végzett elemzések rámutattak, hogy a 18-24 év közötti fiatalok - az idősebb korcsoportok tagjaihoz képest - ritkábban fogyasztanak rostdús élelmiszereket, és ismereti szintjük is bizonytalanabbnak tekinthető. A nők - mint általában a háztartások fó élelmiszer-beszerzői - a témában tudatosabb fogyasztói és vásárlói attitűdöt mutattak, mint a férfiak. A lakhely, illetve az iskolai végzettség tekintetében jelentős eltéréseket nem tapasztaltunk a résztvevők élelmi rostokkal kapcsolatos attitúdjében. Az élelmi rostok fogyasztási mennyisége növelésének szempontjából a gátló tényezők (például érzékszervi kedveltség, anyagi helyzet, hozzáférhetőség) feltárása jelentős információt adhat a további kommunikációs stratégia kialakításához.

$\mathrm{Az}$ internet az egészséges táplálkozással kapcsolatos információszerzés egyik jelentős forrása hazánkban [25, 26], így a hiteles oldalak megismertetése a fogyasztókkal kiemelt fontosságú. Az élelmi rostokkal kapcsolatos fogyasztás előremozdításához, illetve a kapcsolódó hiteles információ átadásához a résztvevők kedvező információs forrásnak tekintették az iskolai oktatást. A közétkeztetés átalakítása és ezzel együtt a rostdús élelmiszerek megjelenése a gyermekek táplálkozásában ígéretes lépésnek tekinthetô. A felnôtt lakosság nevelésének szempontjából kedvező lehet az élelmirost-forrásokra történő rámutatás, valamint azok ételkészítésben betöltött szerepének hangsúlyozása (például teljes kiőrlésú lisztek használata). Továbbá nem szabad megfeledkeznünk az alternatív megoldások népszerúsítéséről, mint például a funkcionális élelmiszerek. Továbbá, a jogi szabályozás szigorodásának, valamint a fogyasztói kommunikáció aktiválódásának hatására információval túlterhelt élelmi- szer-csomagolások közötti eligazodásban a fogyasztók számára segítséget nyújthatnak a modern infokommunikációs eszközök (mobiltelefon-alkalmazások).

A hazai fogyasztók kiegyensúlyozott táplálkozásának érdekében az élelmi rostokkal kapcsolatos hiteles és gyakorlati elemeket tartalmazó iránymutatás és oktatás elengedhetetlen, amelynek eredményeképpen a fokozatosan bővülő látens ismeret várhatóan a fogyasztók vásárlási döntéseiben tudatosan is meg fog jelenni.

Anyagi támogatás: A közlemény megírása anyagi támogatásban nem részesült.

Szerzői munkamegosztás: A munka megtervezésében, a kézirat megszövegezésében és az eredmények értékelésében valamennyi szerző részt vett. Sz. V., H. J.: Adatgyújtés. Sz. V., R. P. F. G.: Adatok értékelése és szövegezése. A cikk végleges változatát mindhárom szerző elolvasta és jóváhagyta.

Érdekeltségek: A szerzőknek nincsenek érdekeltségeik.

\section{Köszönetnyilvánítás}

A munkát a CI\&DETS Research Centre (IPV - Viseu, Portugal) PROJ/CI\&DETS/2014/0001 nemzetközi projekt keretében végeztük.

\section{Irodalom}

[1] Gray, J.: Dietary Fibre. ILSI Europe, Brussels, 2006. http:// www.ilsi.org/Europe/Publications/C2006Diet_FibEng.pdf

[2] Kendall, C. W., Esfahani, A., Jenkins, D. J.: The link between dietary fibre and human health. Food Hydrocoll., 2010, 24(1), $42-48$.

[3] Diet, nutrition and the prevention of chronic diseases. Report of a Joint WHO/FAO Expert Consultation. WHO Technical Report Series 916. Geneva, 2003.

[4] Szeitz-Szabó, M., Biró, L., Biró, Gy., et al.: Dietary survey in Hungary, 2009. Part I. Macronutrients, alcohol, caffeine, fibre. Acta Alimentaria, 2011, 40(1), 142-152.

[5] Sarkadi Nagy, E., Bakacs, M., Illés É., et al.: Hungarian Diet and Nutritional Status Survey - The OTAP2009 study. II. Energy and macronutrient intake of the Hungarian population. [Országos Táplálkozás- és Tápláltsági Állapot Vizsgálat - OTÁP2009. II. A magyar lakosság energia- és makrotápanyag-bevitele.] Orv. Hetil., 2012, 153(27), 1057-1067. [Hungarian]

[6] Zajkás, G.: Hungarian National Nutrition Policy. [Magyarország Nemzeti Táplálkozáspolitikája.] 2004. http://documents.tips/ documents/oeti-magyarorszag-nemzeti-taplalkozaspolitikaja-2004.html [Hungarian]

[7] Antal, E.: Pyramid, rainbow, house. [Piramis, szivárvány, házikó.] Új Diéta, 2001, 1, 17. [Hungarian]

[8] About the $3 \times 3$ a day program. [Fogyasszon naponta $3 \times 3$ féle zöldséget, gyümölcsöt! A naponta $3 \times 3$ programról.] http:// www.3x3.hu/ [Hungarian]

[9] Gil, A., Ruiz-Lopez, M. D., Fernandez-Gonzalez, M., et al.: The FINUT healthy lifestyles guide: Beyond the food pyramid. Adv. Nutr., 2014, 5(3), 358S-367S.

[10] Czukor, B., Kardos, Gy., Vásárhelyiné, P. K.: Analysis of red small fruit rapes for foodstuffs. [Piros bogyós gyümölcs törkölyök élelmi alkalmazását célzó vizsgálatok.] Magyar Táplálkozástu- 
dományi Társaság XXXVI. Vándorgyúlése, 2011. Balatonőszöd. http://www.mttt.hu/portal/downloads/vandorgyules_2011/ Abstract_\%20kotet.pdf [Hungarian]

[11] Bustos, M. C., Perez, G. T., León, A. E.: Sensory and nutritional attributes of fiber-enriched pasta. LWT - Food Sci. Technol., $2011,44(6), 1429-1434$.

[12] Kranz, S., Marshall, Y. M., Wihgt, A., et al.: Liking and consumption of high-fiber snacks in preschool-age children. Food Qual. Pref., 2011, 22(5), 486-489.

[13] Torri, L., Piochi, M., Monteleone, E.: Descriptive sensory analysis and consumers' preference for dietary fibre- and polyphenol-enriched tomato purees obtained using winery by-products. LWT - Food Sci. Technol., 2015, 62(1), 294-300.

[14] Grunert, K. G.: Trends in food choice and nutrition. In: Klopčič, M., Kuipers, A., Hocquette, J. F. (eds.): Consumer attitudes to food quality products. Wageningen Academic Publishers, The Netherlands, 2013.

[15] Regulation (EU) No $1169 / 2011$ of the European Parliament and of the Council of 25 October 2011 on the provision of food information to consumers, amending Regulations (EC) No $1924 / 2006$ and (EC) No 1925/2006 of the European Parliament and of the Council, and repealing Commission Directive 87/250/EEC, Council Directive 90/496/EEC, Commission Directive 1999/10/EC, Directive 2000/13/EC of the European Parliament and of the Council, Commission Directives 2002/67/EC and 2008/5/EC and Commission Regulation (EC) No 608/2004. [Az Európai Parlament és a Tanács 1169/2011/EU rendelete a fogyasztók élelmiszerekkel kapcsolatos tájékoztatásáról, az 1924/2006/EK és az 1925/2006/EK európai parlamenti és tanácsi rendelet módosításáról és a 87/250/EGK bizottsági irányelv, a 90/496/EGK tanácsi irányelv, az 1999/10/EK bizottsági irányelv, a 2000/13/EK európai parlamenti és tanácsi irányelv, a 2002/67/EK és a 2008/5/EK bizottsági irányelv és a 608/2004/EK bizottsági rendelet hatályon kívül helyezéséről.] Az Európai Unió Hivatalos Lapja, 2011, L304, 18-63. [Hungarian]

[16] Grunert, K. G.: 20 years of EUFIC - Consumer information paradox: the evolution of consumer motivations and behaviors. Food Today, The European Food Information Council Newsletter, 2015. http://www.eufic.org/article/en/artid/20_years_ of_eufic_consumer_information_paradox_the_evolution_of_ consumer_motivations_and_behaviours/
[17] Thogersen, J., Jorgensen, A. K., Sandager, S.: Consumer decision making regarding a "green" everyday product. Psychol. Market, 2012, 29(4), 187-197.

[18] Grunert, K. G.: Food quality and safety: consumer perception and demand. Eur. Rev. Agric. Econ., 2005, 32(3), 369-391.

[19] Martinho, C. A., Correia, A. C., Gonçalves, F. M., et al.: Study about the knowledge and attitudes of the Portuguese population about food fibres. Curr. Nutr. Food Sci., 2013, 9(3), 180-188.

[20] Nielsen, A. C.: Functional Food and Organics. A global ACNielsen online survey on consumer behaviour and attitudes. November, 2005. http://foodsecurecanada.org/sites/default/ files/2005_functional_organics_global_online_survey.pdf

[21] Urala, N., Lähteenmäki, L.: Attitudes behind consumers' willingness to use functional foods. Food Qual. Prefer., 2004, 15(78), 793-803.

[22] Guiné, R. P., Martinho, C. A., Barroca, M. J., et al.: Knowledge and attitudes regarding dietary fibres: a consumer survey in Portugese population. Journal of Basic and Applied Research International, 2014, $1(1), 1-12$.

[23] Eurostat: Database. http://ec.europa.eu/eurostat/data/database

[24] Commission Directive 2008/100/EC of 28 October 2008 amending Council Directive 90/496/EEC on nutrition labelling for foodstuffs as regards recommended daily allowances, energy conversion factors and definitions. [A Bizottság 2008/100/EK Irányelve az élelmiszerek tápértékjelöléséről szóló 90/496/EGK tanácsi irányelvnek az ajánlott napi bevitelek, az energiaátváltási együtthatók és fogalommeghatározások tekintetében történő módosításáról.] Az Európai Unió Hivatalos Lapja, 2008, L285, 9. [Hungarian]

[25] Szücs, V., Fülöp, Á., Juhász, Á.: Analysis of age differences in the risk perception of food additives: Results of focus group interviews. Acta Univ. Sapient. Aliment., 2014, 7, 96-108.

[26] Szücs, V., Szabó, E., Bánáti, D.: Exploration of healthy nutrition attitudes using a questionnaire survey. [Az egészséges táplálkozással kapcsolatos attitűdök feltárása kérdőíves megkérdezés alapján.] Orv. Hetil., 2015, 156(16), 636-643. [Hungarian]

(Szücs Viktória dr., Budapest, Herman Ottó út 15., 1022 e-mail: v.szucs@cfri.hu)

\section{Tisztelt Szerzőink, Olvasóink!}

Az Orvosi Hetilapban megjelenő/megjelent közlemények elérhetőségére több lehetőség kínálkozik.

Rendelhető különlenyomat, melynek áráról bővebben a www.akkrt.hu honlapon (Folyóirat Szerzőknek, Különlenyomat menüpont alatt) vagy Szerkesztöségünkben tájékozódhatnak.

A közlemények megvásárolhatók pdf-formátumban is, illetve igényelhető Optional Open Article (www.oopenart.com).

Adott dij ellenében az online közlemények bárki számára hozzáférhetök honlapunkon (a közlemények külön linket kapnak, így más oldalról is linkelhetövé válnak).

Bővebb információ a hirdetes@akkrt.hu címen vagy különlenyomat rendelése esetén a Szerkesztőségtől kérhető. 